Original Article

\title{
Acute and subchronic effects of petroleum on the freshwater fish Hoplias aff. malabaricus
}

\author{
Efeitos agudo e subcrônico do petróleo no peixe de água doce Hoplias aff. malabaricus
}

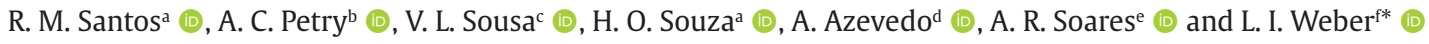 \\ aUniversidade Federal do Rio de Janeiro - UFRJ, Instituto de Biodiversidade e Sustentabilidade - NUPEM, Programa de Pós-graduação em \\ Ciências Ambientais e Conservação - PPG-CiAC, Macaé, RJ, Brasil \\ bUniversidade Federal do Rio de Janeiro - UFRJ, Instituto de Biodiversidade e Sustentabilidade - NUPEM, Laboratório Integrado de Biologia de \\ Vertebrados, Macaé, RJ, Brasil \\ cFundação Oswaldo Cruz - FIOCRUZ, Laboratório de Patologia e Biointervenção, Instituto Gonçalo Moniz, Salvador, BA, Brasil \\ dUniversidade Federal do Rio de Janeiro - UFRJ, Instituto de Biodiversidade e Sustentabilidade - NUPEM, Laboratório Integrado de Morfologia, \\ Macaé, RJ, Brasil \\ eUniversidade Federal do Rio de Janeiro - UFRJ, Instituto de Biodiversidade e Sustentabilidade - NUPEM, Laboratório Integrado de Diversidade \\ Biológica, Química e Molecular, Macaé, RJ, Brasil \\ fUniversidade Federal do Rio de Janeiro - UFRJ, Instituto de Biodiversidade e Sustentabilidade - NUPEM, Laboratório de Biologia Molecular, \\ Macaé, RJ, Brasil
}

\begin{abstract}
Petroleum water soluble fraction (WSF) impairs organisms, but damages may vary among cell and tissue levels. The aim of the present study was to evaluate the acute ( $24 \mathrm{~h}, 48 \mathrm{~h}, 72 \mathrm{~h}$ ) and subchronic effects (36 days) of WSF $(0 \%, 25 \%$ and $100 \%)$ in juveniles of the Neotropical top predator fish Hoplias aff. malabaricus. The effects of WSF were evaluated at a molecular level using the comet assay and micronucleus test for genome damage; and at a morphological level through histological identification of liver pathologic lesions. In both acute and subchronic exposure we found low levels of DNA damage ( $<10 \%$ of comet tail) and non-significant frequency of micronucleus in WSF exposed fish. The most significant liver lesions in WSF exposed fish were fatty vacuolization, hypertrophy and focal necrosis. Since these tissue injuries were progressive and persistent, their irreversibility may negatively affect fish recruitment, even in a such resistant top predator.
\end{abstract}

Keywords: Brazil, comet assay, micronucleus, necrosis, PAH.

\section{Resumo}

A fração solúvel de petróleo (WSF) prejudica os organismos, porém os danos podem variar entre os níveis celular e tecidual. O objetivo do presente estudo foi avaliar o efeito agudo ( 24 h, 48 h e 72 h) e subcrônico ( 36 dias) da WSF (0\%, 25\% e 100\%) em juvenis do peixe neotropical predador topo Hoplias aff. malabaricus. Os efeitos da WSF foram avaliados no nível molecular utilizando o ensaio do cometa e o teste do micronúcleo para o dano genômico e no nível morfológico através da identificação histológica de lesões patológicas no fígado. Em ambas exposições (aguda e subcrônica) encontramos baixos níveis de dano no DNA (< 10\% de DNA na cauda do cometa) e frequência de micronúcleos não significativa em peixes expostos a WSF. As lesões mais significativas no fígado dos peixes expostos a WSF foram a vacuolização lipídica, hipertrofia e focos de necroses. Como estas lesões foram progressivas e persistentes, sua irreversibilidade pode afetar negativamente o recrutamento dos peixes, mesmo sendo um predador topo resistente.

Palavras-chave: Brasil, ensaio do cometa, micronúcleo, necrose, HPA.

\section{Introduction}

Brazil currently occupies the sixth position on crude oil production, which comprises approximately $5.5 \%$ of the world amount (Trading Economics, 2019). Within the southeast coast of the country, the Campos Basin oil field corresponds historically to one of the most productive offshore areas, concentrating platforms, stocking ducts,

and heavy vessels traffic related to petroleum extraction activities. Although marine compartments are much more susceptible to contamination risks from offshore oil spills, hundreds of coastal waterbodies, such as shallow lagoons [that in Brazil are mostly concentrated along the southeast coast (Petry et al., 2016)] may also be contaminated

*e-mail: lauraweberufrj20@gmail.com

Received: June 29, 2021 - Accepted: October 19, 2021

This is an Open Access article distributed under the terms of the Creative Commons Attribution License, which permits unrestricted use, distribution, and reproduction in any medium, provided the original work is properly cited. 
throughout seawater intrusion, percolation and sandbar breaking. Within the freshwater fish assemblages that inhabit these environments, the trahira Hoplias aff. malabaricus (Bloch, 1794) occupies the top position of the food chains. This species is widespread through almost all hydrographic basins of South America and exerts a keystone effect (Oyakawa, 2003; Petry et al., 2010; Silva et al., 2011). This sedentary and ambush fish since the juvenile stage has been used as a model in several experimental studies, which investigated the effects of temperature over growth and prey consumption (Petry et al., 2007); of pesticides over liver tissue (Miranda et al., 2008); of metals and pesticides over DNA (Cestari et al., 2004; Ferraro et al., 2004; Ramsdorf et al., 2009); and of petroleum over feeding and growth rates (Santos et al., 2016).

The toxicity of the water soluble fraction of petroleum (hereafter named WSF) derives from the processes of spreading, drifting, evaporation, dissolution, photolysis, biodegradation of oil and its conversion to petroleum metabolites (Mackay and McAuliffe, 1988; Daling et al., 1990). WSF of crude oil contains aromatic hydrocarbons, phenolic and heterocyclic compounds with nitrogen and sulfur elements (Saeed and Al-Mutairi, 1999), most of them potentially carcinogenic (Khan et al., 1995; Woo et al., 2006). Polycyclic aromatic hydrocarbons (PAH) such as pyrene, chrysene, benzo(b)fluoranthene, benzo(a)pyrene (known as carcinogenic PAHs) are largely recognized as genotoxic (Hamouten et al., 2002; Jha, 2004; Lemos et al., 2007; Weber et al., 2013). Their toxic effects have been widely reported on aquatic organisms after oil-spillages (Collier et al., 1996; Nicodem et al., 1997; Bue et al., 1998; Saeed and Al-Mutairi, 1999; Peterson et al., 2003; Akaishi et al., 2004; Pérez-Cadahía et al., 2004). The high absorption rates of WSF components determine immediate toxic effects in aquatic organisms and may also bioaccumulate in some of them, in a process that reverberate negative effects throughout the trophic chain (Collier et al., 1996; Akaishi et al., 2004). Due to the presence of polar components, WSF has been considered even more toxic than droplets (Zhou et al., 1994; Nicodem et al., 1997; Vanzella et al., 2007). As the increasing use of petroleum and derivates makes practically impossible to escape from environmental contamination (Laws, 1993), the evaluation of the WSF of crude-oil from a top-down perspective (i.e., on top predators) is still necessary for both understanding the sensitivity of aquatic organisms and consequences on the population and food chain levels (Sedeño-Díaz and López-López, 2012).

Bioassays allow to detect damage response both at the genomic (ex. Gomes et al., 2019) and histological levels (ex. Paulo et al., 2012; Al-Otaibi et al., 2019), where micronucleus frequency and histopathological lesions may represent the "early warning" of physiological disturbances (Costa, 2018; Couoh-Puga et al., 2021). In this study, we simulated both acute and subchronic petroleum WSF contamination in Hoplias aff. malabaricus to understand the extent of genomic and organ damage in such a top predator fish at different times of exposure.

\section{Material and Methods}

\subsection{Animals and acclimation}

Juveniles of Hoplias aff. malabaricus showing a size range of $12.6 \pm 4.8 \mathrm{~cm}$ total length were captured in coastal lagoons at the North of the state of Rio de Janeiro between September 2011 and May 2012, and transported alive to the aquatic bioterium of the Instituto de Biodiversidade e Sustentabilidade, Universidade Federal do Rio de Janeiro (NUPEM/UFRJ). They were acclimated for 15 days in $12 \mathrm{~L}$ tank of clean freshwater at $25 \pm 1{ }^{\circ} \mathrm{C}$ with constant aeration. They were fed every $72 \mathrm{~h}$ with alive commercially acquired tetra fish (Hyphessobrycon eques), when $70 \%$ of the water was exchanged. Feeding was suspended $72 \mathrm{~h}$ before the initiation of the acute and subchronic tests.

\subsection{Preparation of Water Soluble Fraction (WSF)}

Water soluble fraction in accordance to Anderson et al. (1974) represents the behavior of crude oil in the environment, which concentration will depend on the proximity in time and distance of the spillage event and the intensity of waves action. Therefore, a wide range of concentrations of WSF will be observed between the spillage event and the complete decontamination of the affected area.

The heavy crude oil (API 17ㅇ; Trevisan et al., 2009) was obtained from the Jubarte oil field situated at $77 \mathrm{~km}$ off the southeast of Brazil, which composition of benzene, ethylbenzene, toluene and xylene (BTEX analysis) are shown in Table 1. WSF preparation followed Anderson et al. (1974) with modifications (for details, see Santos et al., 2016). Modifications were based on a previous work (Weber et al., 2013), which used the relation of Jubarte

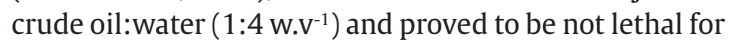
a much more sensible organism (amphipod, Crustacea; $\mathrm{LC}_{50(72 \mathrm{~h})}=51 \% \mathrm{WSF}$ ) at the level of $17.6 \%$ WSF. Afterwards, in preliminary bioassays ( $48 \mathrm{~h}$ and $72 \mathrm{~h}$; data not shown) it was confirmed that these concentrations are sublethal for the trahira. One part of crude oil $(1.2 \mathrm{Kg})$ was mixed with four parts of filtered and sterilized tap water $(4.8 \mathrm{~L})$ $\left(1: 4 \mathrm{~W} \cdot \mathrm{v}^{-1}\right)$ and homogenized with a magnetic stirrer for $24 \mathrm{~h}$ at $500 \mathrm{rpm}$ in dark. Afterwards, the mixture was transferred to a settling funnel and left for $2 \mathrm{~h}$, when the lower phase (water fraction) was collected. This freshly obtained fraction was considered the 100\% WSF, from which the $25 \%$ dilution was prepared by adding freshwater. The $100 \%$ WSF composition was determined in the CQA Laboratory (Centro de Qualidade Analítica, Campinas, São Paulo) (see Table 1). BTEX analysis of this fraction did not detected components at the level of $0.0020 \mathrm{mg} \mathrm{L}^{-1}$. Therefore, a qualitative analysis of this fraction was performed in the Chemistry Laboratory of NUPEM/UFRJ and employed gas chromatography and mass spectrophotometry (Shimadzu CGMS-QP2010 Plus). The WSF fraction was submitted to liquid-liquid partition using solvents of increased polarity (three steps): hexane, dichloromethane and butanol. For each step, $600 \mathrm{~mL}$ of WSF and $30 \mathrm{~mL}$ of extraction solvent were used. The mixture was stirred and the organic phase was collected. The extraction was repeated with 
Table 1. Components in crude oil and in100\% WSF used in this study.

\begin{tabular}{|c|c|c|c|c|c|}
\hline \multicolumn{2}{|c|}{$\begin{array}{l}\text { Crude Oil } \\
\text { BTEX Analysis }\end{array}$} & \multicolumn{4}{|c|}{$\begin{array}{c}100 \% \text { WSF } \\
\text { Qualitative Analysis }\end{array}$} \\
\hline Component & $\left(\mathrm{mg} \mathrm{L}^{-1}\right)^{\mathrm{a}}$ & Classes of Organic Compounds & $\% \mathrm{FH}$ & \% FD & $\% \mathrm{FB}$ \\
\hline Benzene & 392.45 & Aliphatics Hydrocarbons (linear and branched) & 22.3 & 3.3 & 1.8 \\
\hline Toluene & 542.38 & Monoaromatic Hydrocarbons & 63.8 & 23.6 & 2.6 \\
\hline Ethylbenzene & 58.96 & Aromatics Hydrocarbons & 5.1 & 0 & 90.9 \\
\hline \multirow[t]{2}{*}{ Xylene } & 169.81 & Olefins Hydrocarbons & 0 & 4.4 & 0 \\
\hline & & Other components & 5.5 & 40.8 & 0 \\
\hline
\end{tabular}

aCQA laboratory, detection level of $0.0020 \mathrm{mg} \mathrm{L}^{-1} ;{ }^{\mathrm{b}} \mathrm{CG} / \mathrm{MS}$ at Laboratório Integrado de Química, NUPEM/UFRJ; Results were expressed as relative percentage of organic classes in the fractions. \% FH: hexane fraction; \% FD: dichloromethane fraction; \% FB: butanol fraction.

each solvent. At the end of each step, the solvent was evaporated using a rotaevaporator Buchi R-210/R-215 and the hexane, dichloromethane and butanol fractions were obtained. Chemical profiles were then compared to the NIST 2008 library. Results were expressed as relative percentage of organic classes in each fraction.

\subsection{Experimental design}

Four independent experiments differing in time of exposure (acute tests: 24 h, 48 h, 72 h; subchronic test: 36 days) were carried out between October 2011 and June 2012. In all experiments fish were exposed to the following treatments: 0\% WSF (control), 25\% WSF and 100\% WSF. During the acute tests, 4 fish/treatment/time of exposure were allocated in individual $8 \mathrm{~L}$ aquaria without feeding and water exchange; constant aeration and water temperature of $25 \pm 1{ }^{\circ} \mathrm{C}$. During the subchronic test, 5 fish/treatment were allocated in individual $8 \mathrm{~L}$ aquaria without feeding and with weekly water exchange; constant aeration and water temperature of $25 \pm 1{ }^{\circ} \mathrm{C}$. At the end of each exposure time, fish were sedated with $6.7 \mathrm{~mL} \mathrm{~L}^{-1}$ benzocaine bath obtained from an ethanol stock solution of $80 \mathrm{~g} \mathrm{~L}^{-1}$. Then, blood was extracted from the caudal vein using a $0.1 \mathrm{M}$ EDTA pre-coated $1 \mathrm{ml}$-syringe for the subsequent tests of genotoxicity. Fish were then euthanized by a cervical section incision and immediately the liver was removed and fixed in Bouin ( $75 \mathrm{~mL}$ picric acid; $25 \mathrm{~mL}$ formaldehyde 40\%; $5 \mathrm{~mL}$ glacial acetic acid) for histological analysis. Procedures were in accordance with the Brazilian legislation and were authorized by the Ethics Committee of Animal Experimentation of the Federal University of Rio de Janeiro (\#Macae09/2012).

\subsection{Genotoxicity tests}

\subsubsection{Comet assay}

Fresh blood $(5 \mu \mathrm{L})$ was mixed with $100 \mu \mathrm{L} 0.5 \%$ low melting agarose (LMA) and poured over the pre-coated slide with $1 \mathrm{~mL} 0.5 \%$ agarose. An additional layer of $100 \mu \mathrm{L}$ $0.5 \%$ LMA was added to the slide. The preparation was submitted first to lysis buffer $(2.5 \mathrm{M} \mathrm{NaCl}, 10 \mathrm{mM}$ Tris, $100 \mathrm{mM}$ EDTA, $1 \%$ SDS, 10\% DMSO, $1 \%$ de Triton X-100, pH 10) for $20 \mathrm{~min}$ at $4-7^{\circ} \mathrm{C}$ in dark; secondly was denatured in alkaline solution (300 mM NaOH, 1 mM EDTA, pH > 13) for $20 \mathrm{~min}$ and immediately submitted to electrophoresis at $320 \mathrm{~mA}$ and 33 volts for another $20 \mathrm{~min}$. On the last step, slides were neutralized with Tris- $\mathrm{HCl}, \mathrm{pH} 7.0$ and fixed with absolute ethanol. The reduced time of each step was already tested by Weber et al. (2013). After drying at room temperature, the samples in the slides were stained with fluorescent DAPI (4'6'-diamidino-2-Phenylindol) dye and visualized in epifluorescent microscope (Olympus). One hundred comets (nucleoids of erythrocytes) per fish were photographed and the following measurements were taken from each comet using the CometScore ${ }^{\mathrm{TM}}$, v.1.6.1.13 software (TriTek Co.): (CL) comet length, (TL) tail length, (\%T) \% of DNA in tail, (TM) tail moment and (OM) olive moment. Measures of central tendency of those measures (means) were compared between fish exposed and non-exposed to WSF by Mann-Whitney U test.

\subsubsection{Micronuclei test}

Fish blood sample was smeared over a clean slide immediately after extraction. Those slides were left to dry overnight at room temperature and then fixed with methanol. Afterwards, smears were stained with fluorescent dye, $0.01 \%$ acridine orange, and 2,000 cells/fish were counted using an Olympus epifluorescent microscope. The number of micronuclei (MN) was expressed every 1,000 cells. Due to large variances within each treatment (and therefore non-normality checked by KolmogorovSmirnov test), MN data were logarithm transformed [Log $(\mathrm{MN}+1)]$. MN transformed values were compared between WSF exposed (25\%WSF and 100\% WSF) and non-exposed (0\%WSF) fish by Mann-Whitney U test.

\subsection{Histopathological analysis}

Liver samples were dehydrated in a serial of ethanol dilutions followed by the inclusion in Paraplast-Plus (Sigma) resin. Inclusions (resin blocks) were submitted to an automatized microtome (Leica, RM-2155) to obtain sections of liver tissue of $5 \mu \mathrm{m}$ thickness. On average, ten sections per replicate were stained with hematoxylin/ eosin and examined in an optic Olympus microscope using the PDC Controller software for image capture. Histological alterations were identified and categorized using quantitative and qualitative criteria in accordance 
to Bernet et al. (1999). Histopathological lesions in four reaction patterns encompassed liver tissues alterations (ALT): 1. Circulatory disturbances, which evaluated the conditions of blood and fluid flow, herein limited to blood vessel congestion; 2. Regressive changes, which determine malformation or dysfunction of cellular structures as a result of cell damage, herein a) fatty vacuolization, b) granule deposits, c) nuclear alterations and d) necrosis; 3. Progressive changes, which lead to an increased activity of cells and tissues, herein limited to hypertrophy; and 4. Inflammation, often associated to other reaction patterns, herein a) cell infiltrations, b) melanomacrophage aggregates and c) lipogranulomes. Each alteration received a pre-stablished value in accordance to its pathological importance sensu Bernet et al. (1999), called "importance factor" $(w)$ : where, $w=1$, represents minimal pathological importance (lesions that are easily reversed as exposure ends); $w=2$, represents moderate pathological importance (still reversible lesions in most cases if the stressor is neutralized) and $w=3$, represents marked pathological importance (generally non-reversible lesions, leading to partial or total loss of organ function). Therefore, most alterations received score $1(w=1)$, whereas nuclear alterations and inflammatory infiltrates received score $2(w=2)$ and necrosis, score $3(w=3)$. The extension of the pathological change $(a)$ is rated by a "score value" (Bernet et al., 1999), where $a=0$ means unchanged, $a=2$ is mild occurrence, $a=4$ is moderate occurrence, and $a=6$ is severe occurrence (diffuse lesion). The alteration index $\left(\mathrm{I}_{\mathrm{alt}}=w \times a\right)$ was calculated for each fish and the average of each treatment was compared. The reaction pattern index $\left(\mathrm{I}_{\mathrm{rp}}=\Sigma \mathrm{I}_{\mathrm{alt}}\right)$ represents the sum of the mean alteration indexes, whereas the liver index $\left(\mathrm{I}_{\mathrm{org}}=\Sigma \mathrm{I}_{\mathrm{rp}}\right)$ represents the sum of the reaction patterns (see Bernet et al., 1999). The Induction Factor (IF; Šrut et al., 2011) represents the ratio between the $\mathrm{I}_{\text {alt }}$ obtained from WSF exposure unit and $\mathrm{I}_{\text {alt }}$ from its respective control. Mean comparisons between WSF exposed and non-exposed units and between different treatments were performed using Mann-Whitney U test, whereas for the effect of time of exposure comparisons were performed by Kruskal-Wallis test. Whenever the multiple comparisons detected significant differences, the post-hoc Duncan test was performed to determine which exposition times most affected the response variables. We assumed a significance level $\alpha=0.05$ and used the statistical package STATISTICA for Windows, v. 5 (Statsoft, Inc.) for graphs and analyses.

\section{Results}

The exposure of juveniles of $H$. aff. malabaricus to petroleum WSF revealed in general low levels of DNA damage ( $<10 \%$ tail DNA), but most comet measurements (CT, TL, \%T, TM, OM) revealed significant differences between exposed and non-exposed individuals in both acute and subchronic tests (Figure 1). The pairwise comparison evidenced that $25 \%$ WSF was the most genotoxic treatment by the higher damage both on acute ( $48 \mathrm{~h}$ ) and subchronic (36 days) exposure, whereas $100 \%$ WSF was most significant on acute $(72 \mathrm{~h}$ ) exposure (Figure 1 ). Micronuclei were low in the first $48 \mathrm{~h}$ of exposure, not differing among treatments. After $72 \mathrm{~h}$ of exposure the increase of variation in individual fish response was more evident (Figure 2A), although this pattern was also evident in the controls. Therefore, no significant differences were detected in MN between treated and control fish (Figure 2B).

The hepatic parenchyma shows pancreatic tissue formed by acinar cells rich in zymogenic granulations with diffuse distribution and associated to the blood vessels. Hepatocytes arranged in linear structures, surrounding sinusoidal capillaries and irradiating in direction to the central vessel were observed in liver tissue of most of the non-affected fish, those from control units. These ones also showed hepatocytes characterized by homogeneous cytoplasm and granulations, spherical nucleus and prominent nucleolus. The central veins, hepatic sinusoids and biliary ducts were preserved (Figure 3A, C, E). On the other hand, WSF exposed fish showed accumulation of lipid drops in hepatocytes (lipid vacuolization) (Figure 3B) and brown and eosinophilic coarse grains were observed in the cytoplasm. Perivascular inflammatory infiltrated areas were also seen in those samples. The presence of melanomacrophage aggregates of various sizes were mainly observed around the capsule region containing macrophage-like cells with brown pigmentation and inflammatory infiltrated cells. Also, discrete number of lipogranulomes in the parenchyma were observed, which were formed of fat globules in different number and sizes, surrounded by mononuclear inflammatory cells and brown pigments deposits. Some significant changes were also observed in WSF treated fish, such as fatty vacuolization (Figure 3B), nuclear degenerations, hypertrophy (Figure 3D) and necrosis (Figure 3F). Most alterations, such as nuclear alterations, focal areas of necrosis, increase of cell volume (hypertrophy) and leucocyte infiltration were observed at the first $24 \mathrm{~h}$ of exposure.

Discrete blood vessels congestions, granule deposits and the increase of lipid drops in the hepatocytes (fatty vacuolization) began at $48 \mathrm{~h}$ of WSF exposure (Figure 4A). Fatty vacuolization and necrosis were observed at the end of the subchronic test (at 36 days) as increased and persistent lesions (Figure 4A). Bile stagnation and increase of melanomacrophage aggregates were not related to WSF exposure, since they were present in both controls and treated fish.

The significantly toxic effects of WSF in the trahira was evidenced by nuclear alterations on the first $24 \mathrm{~h}$ of exposure $(p=0.0006)$, characterized by abnormal size and form, chromatin condensation and glycogen inclusion, which were not maintained afterwards. Significant toxicity was also observed by perivascular focal necrotic points at both concentrations $(25 \%, p=0.0420 ; 100 \%, p=0.0110)$ in the acute test and also in the subchronic test $(p=0.0052)$. Hypertrophy was characterized by the significant increase of hepatocyte volume only at $25 \% \operatorname{WSF}(p=0.0170)$, but no more evident in the subchronic test $(p=0.0212)$, showing a positive effect of time. Fatty vacuolization, on the other hand increased with time of exposure $(p=0.0159)$. When comparing the global mean changes, fatty vacuolization, necrosis and hypertrophy were significantly altered in 


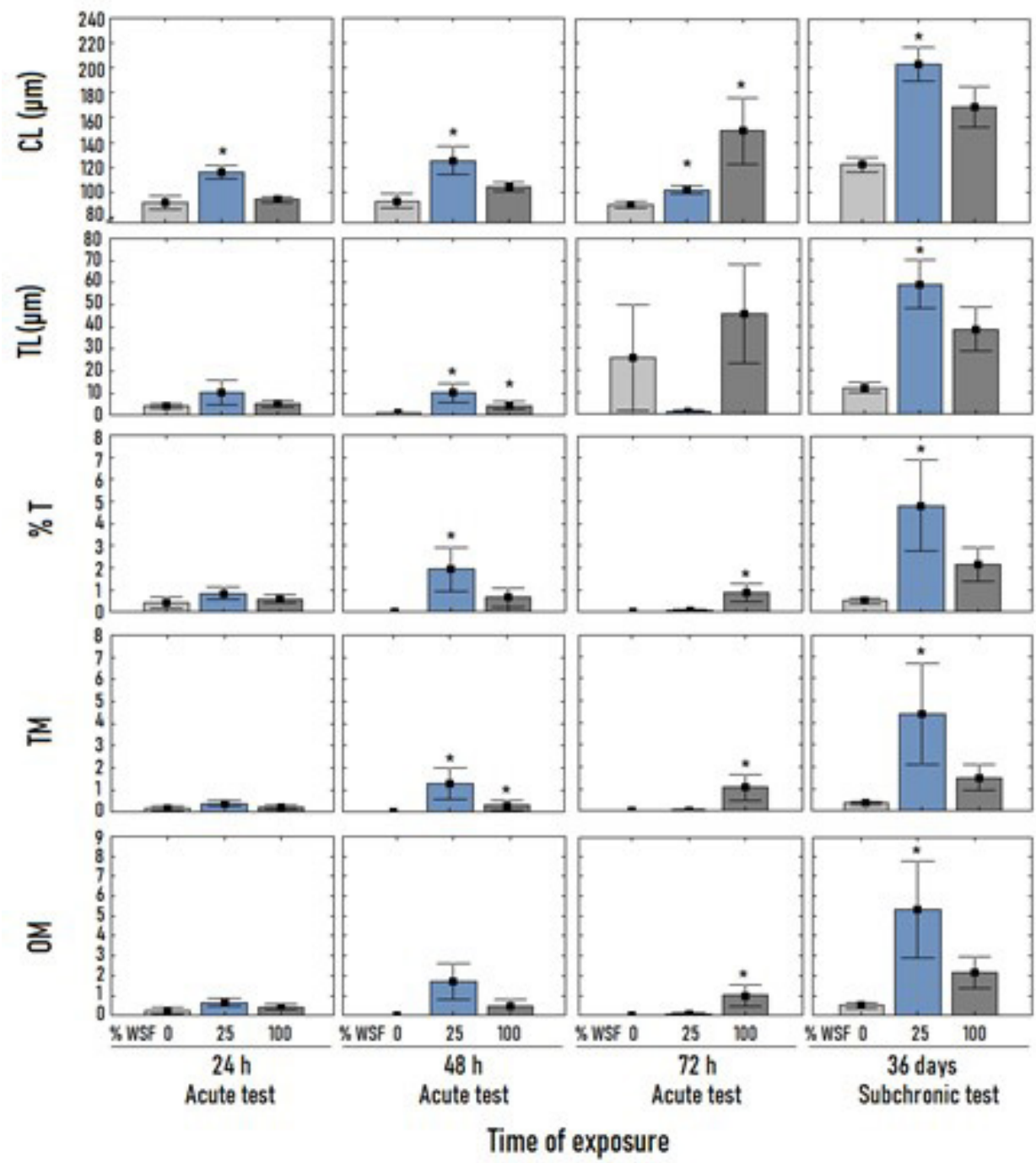

Figure 1. Levels of DNA damage (mean \pm standard error) in erythrocytes of Hoplias aff. malabaricus in four independent experiments with different times of exposure: three acute tests ( $24 \mathrm{~h}, 48 \mathrm{~h}$ and $72 \mathrm{~h} ; \mathrm{N}=4$ /treatment and time of exposure) and one subchronic test (36 days; $\mathrm{N}=5$ /treatment). Controls were represented by $0 \% \mathrm{WSF}$, and all experiments tested $25 \%$ WSF and $100 \%$ WSF. For each fish, 100 comets (nucleoids) were evaluated. The mean of a treatment represents the mean across individual means. (CL) comet length, (TL) tail length, (\%T) \% of DNA in tail, (TM) tail moment and (OM) olive moment. Significance of DNA damage $\left({ }^{*}\right)$ at WSF treatments were evaluated against the respective control.

the trahira under WSF exposure (Figure 4B), with values significantly higher than those observed in controls.

\section{Discussion}

The resistance of $H$. aff. malabaricus for adverse environmental conditions have been reported previously, from long-term food deprivation to contamination with heavy metals (Rantin et al., 1992; Rios et al., 2002; Petry et al., 2007; Ramsdorf et al., 2009). Nonetheless, an immediate negative response to the contact with contaminated waters are not the rule in fish species and responses to PAH may vary largely among species
(Gernhöfer et al., 2001). We found that the timing of genotoxic response of $H$. aff. malabaricus varied accordingly to WSF concentrations. Fish absorption rates depends both on the degree of exposure to the contaminant and also on its lipid content (Moore and Ramamoorthy, 1947). Petroleum is a mixture of thousand hydrocarbons and nonhydrocarbons compounds, where the first may compose up to $75 \%$ of the mixture (Albers, 2003). All hydrosoluvel and dropped lipid compounds may enter in different proportions into the WSF and aromatics may represent $96 \%$ of these compounds, being the monoaromatics and naphthalenes the most represented PAHs (Frantzen et al., 2012). Hydrocarbons compounds are absorbed selectively 
A

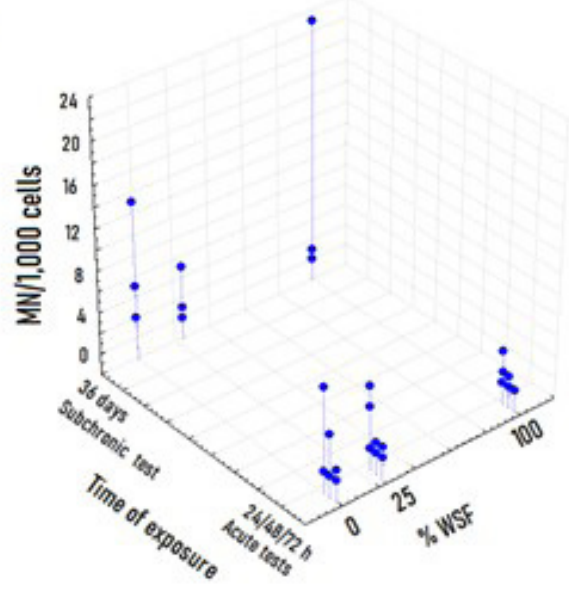

B
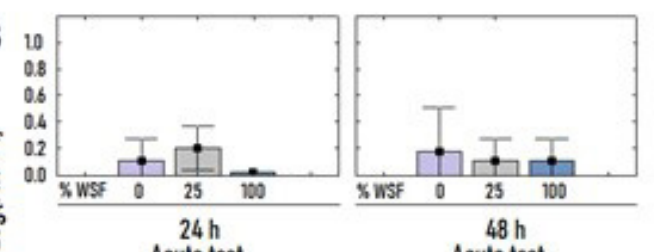

Acute test

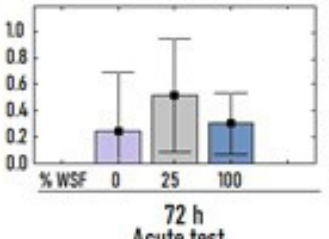

Acute test

Time of Exposure

Figure 2. Results of Micronucleus Test in erythrocytes of Hoplias aff. malabaricus measured in 2,000 cells/fish. A) Number of micronucleus every thousand cells $(\mathrm{MN} / 1,000)$ found in every fish after acute exposure ( $24 \mathrm{~h}, 48 \mathrm{~h}, 72 \mathrm{~h}$ ) and subchronic exposure (36 days) to different WSF concentrations (0\%WSF, representing the control; 25\%WSF and 100\%WSF); B) Means of Log transformed micronuclei $/ 1,000$ cells $[\log (\mathrm{MN}+1)]$ (means \pm standard deviations) for each treatment at different time of exposure. $\mathrm{N}=4$ /treatment/ time of exposure for the acute tests and $\mathrm{N}=5 /$ treatment for the subchronic tests.

at different rates and may be deposit in different tissues such as liver, adipose and bone tissues; may be catalyzed by enzymes to hydrosoluvel components and be excreted (Pedrozo et al., 2002). By using the same WSF as those adopted in the present work, we previously detected only mild effects on growth and prey consumption of juvenile $H$. aff. malabaricus and attributed the resistance and/or the capacity of excretion of components metabolized by the liver of the top-predator as reasonable mechanisms to explain those findings (Santos et al., 2016). But the high metabolic and hydrocarbon metabolites excretion rates of fish (Mason, 1945) may explain the low cellular and molecular damage found in $H$. aff. malabaricus.

Polycyclic aromatic hydrocarbons require metabolic activation before the occurrence of DNA damage, which involves the generation of reactive oxygen species by quinones and other aromatic nitro compounds (Lee and Steinert, 2003). By considering that genotoxicity should be a more sensible test than effects on the level of the individual, we expected a higher damage response in trahiras submitted to WSF exposure. At 36 days of WSF exposure, trahiras showed levels of DNA damage much lower $(39.5 \pm 33.4 \mu \mathrm{m}$ tail length) than those found in the flounder Paralichthys olivaceus after $48 \mathrm{~h}$ exposure to sediments contaminated with $10 \mathrm{ppb}$ of benzo[a]pyrene (76 $\pm 9.5 \mu \mathrm{m}$ tail length; Woo et al., 2006). Micronucleus formation normally requires longer exposure to contaminant than the DNA damage detected by the comet assay, thus suggesting mutagenesis and potential future decline of the population. Çavaş and Ergene-Gözükara (2005) found as much as $6.5 \mathrm{MN} / 1,000$ in grey mullet erythrocytes in areas contaminated with PAH. Since trahira did not show significant frequency of MN after 36 days of WSF exposure, we cannot predict mutagenesis in the population, neither to rule out the possibility of recovery, since it has been reported in other fish species (Moreira et al., 2014; Medeiros et al., 2017).

The liver is one of the most affected organs by contaminants (ex. Paulo et al., 2012; Al-Otaibi et al., 2019) and plays a key role in metabolism with the subsequent excretion of xenobiotics, detoxification and biotransformation processes (Bernet et al., 1999; Camargo and Martinez, 2007; Agamy, 2012). Histological lesions (circulatory disturbances, inflammatory processes, regressive and progressive changes) observed in the trahira were mostly similar to those found in the licking fish Astyanax sp. (Akaishi et al., 2004) and in the rabbit fish Siganus canaliculus (Agamy, 2012). Fatty vacuolization in the trahira was evident mainly after $72 \mathrm{~h}$ of exposure, which may be an indicative of the liver oil retention and probable subsequent elimination. Increased lipid vacuolation were also observed in the rabbit fish (Agamy, 2012) and has also been attributed to increased glycogen reserve in stressed animals (Camargo and Martinez, 2007). However, differently from Camargo and Martinez (2007) findings, we did not found differences in bile stagnation neither in melanogranulomes in the liver of the exposed and non-exposed trahiras.

Irreversible liver damage in the trahira, such as focal necrosis, was evident from the first $24 \mathrm{~h}$ of WSF exposure. Although liver necrosis did not result in death during the trials, these liver disorders may induce to population declination with time. It is possible that most severe damage might occur earlier in the ontogeny, due to the higher sensitivity of the embryonic and larval stages compared to the juveniles. Systemic effects have been verified in other fish species after exposure to PAH due to high accumulation and low biotransformation at those initial stages (Barron et al., 2004; Frantzen et al., 2012). In addition, Bue et al. (1998) and Heintz et al. (2000) observed decline of gametes survival in adult pink salmon after two years of being exposed in the embryonic stage to PAH from the Exxon Valdez oil spill. We recorded values $\left(I_{\text {alt }}=5\right)$ of necrosis at 36 days of WSF exposure in the trahira, similar of those found in S. canaliculus after 21 days of exposure to water accommodated fraction 

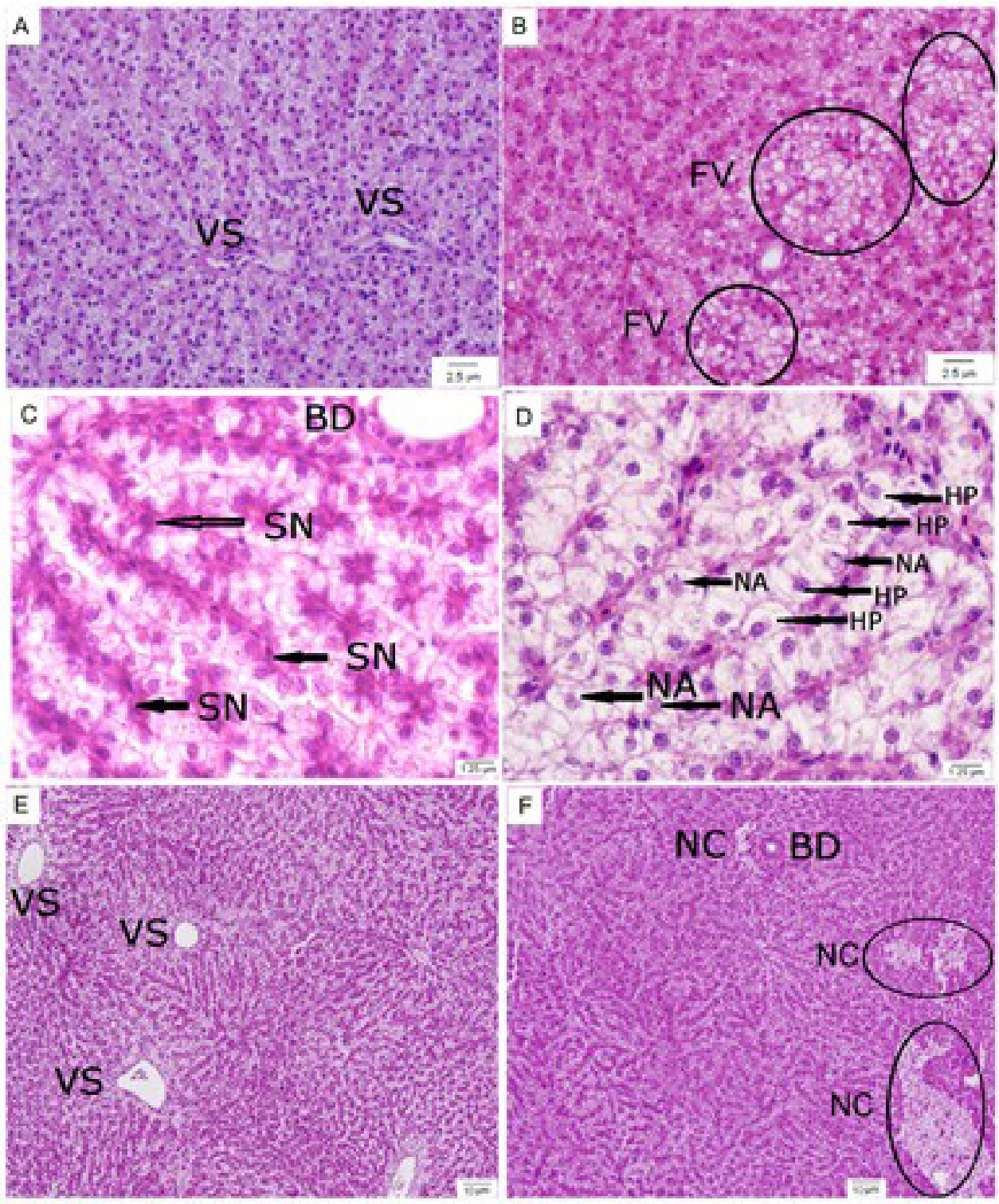

Figure 3. Histological alterations of reaction patterns observed in Hoplias aff. malabaricus liver observed in 4 fish/treatment/time of exposure for the acute tests ( $24 \mathrm{~h}, 48 \mathrm{~h}, 72 \mathrm{~h}$ ) and 5 fish/treatment for the subchronic tests (36 days): A) Normal fatty vacuolization (control, 0\%WSF), B) Increased fatty vacuolization (FV) after 36 days of exposure to 25\% WSF; C) Normal cells (control, 0\%WSF); D) Nuclear alterations (NA) and hypertrophy (HP) after $24 \mathrm{~h}$ of exposure to $25 \%$ WSF; E) Normal cells (control, $0 \%$ WSF) and F) focal necrosis (NC) after $72 \mathrm{~h}$ exposure to $100 \%$ WSF. (BD) biliary ducts, (SN) sinusoids, (VS) veins.

(6\% WAF) of petroleum (Agamy, 2012). Necrotic areas in acute exposure observed in this study after $24 \mathrm{~h}$ were also found in Astyanax sp. liver from the first $12 \mathrm{~h}$ of exposure at different WSF concentrations (Akaishi et al. 2004), indicating that liver necrosis may be a useful histological parameter for tissue damage by contamination even in more resistant species.

The toxicity of petroleum and WSF still remains an important task due to the increasing petroleum industry and use of those components for energy supply, leading to a higher probability of leaking events and oil spills, such as the recently thousands of tons of crude oil residue dispersed on the Brazilian coast (Barboza et al. 2019).

The top predator fish Hoplias aff. malabaricus showed to be resistant at the molecular level (low genomic damage: $<10 \%$ tail DNA and non-significant micronucleus number) at $25 \%-100 \%$ WSF ( $1: 4 \mathrm{w} / \mathrm{v})$ heavy oil exposure from Jubarte oil field. Nonetheless, somatic effects as liver pathologic lesions were the most significant and persistent effects, from which fatty vacuolization and focal necrosis persisted at short and long-term WSF exposure. The progressive and irreversible tissue injury represented by the focal necrosis 

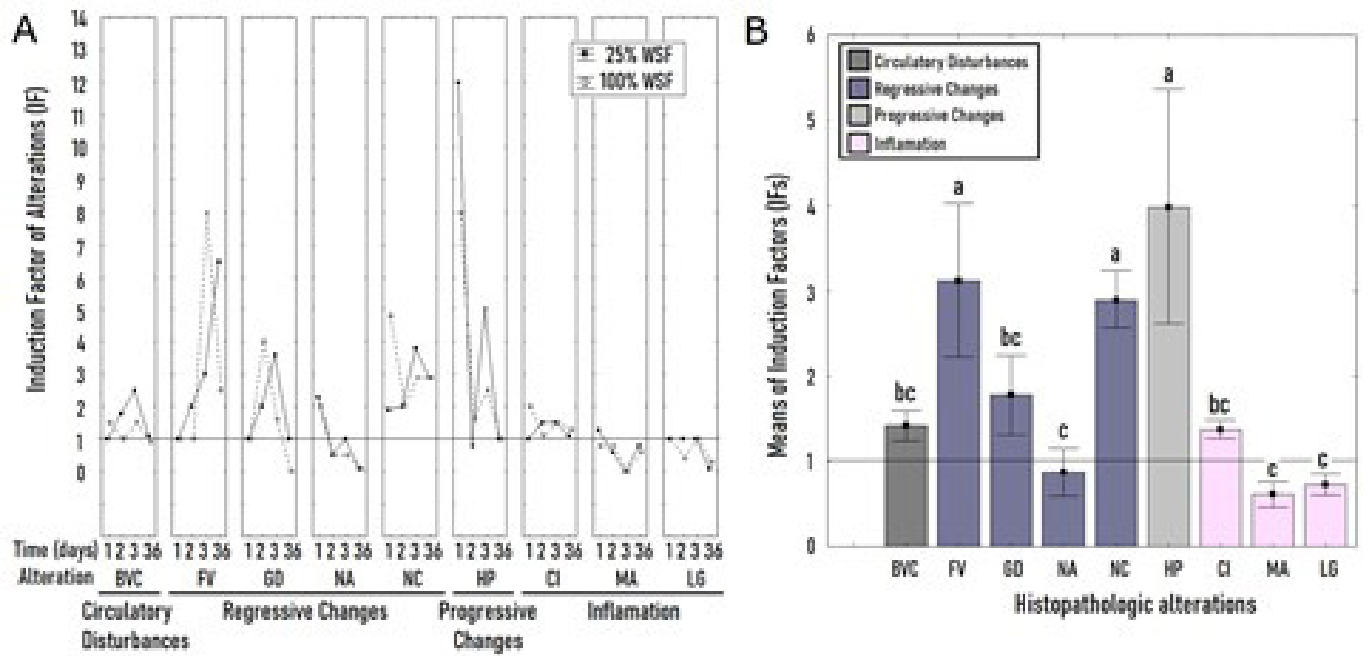

Figure 4. Induction factor as a measure of liver histopathologic damage at different kind of alterations of reaction patterns in Hoplias aff. malabaricus exposed to different WSF concentrations and times of exposure, as observed for 4 fish/treatment/time of exposure for the acute tests ( $24 \mathrm{~h}, 48 \mathrm{~h}, 72 \mathrm{~h}$, here expressed in days) and 5 fish/treatment for the subchronic tests (36 days). (BVC) blood vessel congestion; (FV) fatty vacuolization; (GD) granule deposits; (NA) nuclear alterations; (NC) necrosis; (HP) hypertrophy; (CI) cell infiltrations; (MA) melanomacrophage aggregates; and (LG) lipogranulomes. Horizontal line indicates IF $=1$, when tissue alteration level in WSF exposed units are equal to those in control units. A) Levels of damage by kind of alteration at different time of exposure; B) Mean level of damage by kind of alteration (mean \pm standard error). In accordance to Duncan test, the letter "a" indicates those alterations (with IF significantly different from 1 ) that differed from those alterations indicated by the letters "b" and "c $c$ " (with IFs that not differed from 1 ).

recorded herein, may compromise liver function with time and, therefore, may negatively affect fish recruitment even in a such resistant top predator.

\section{Acknowledgements}

This study was financed in part by the Coordenação de Aperfeiçoamento de Pessoal de Nível Superior - Brasil (CAPES) - Finance Code 001. We are very grateful to FINEP/ PETROBRAS (3175/06) for the research financial support and to $\mathrm{CNPq}(314865 / 2009-8)$ for the Productivity Research grant to A.C.P. We also thank J.M. de Souza and S. Stoffel (in memorian) for field assistance and J.N. da Silva for assistance with histological processing.

\section{References}

AGAMY, E., 2012. Histopathological changes in the livers of rabbit fish (Siganus canaliculatus) following exposure to crude oil and dispersed oil. Toxicologic Patholology, vol. 40, pp. 1128-1140. https://doi.org/10.1177\%2F0192623312448936.

AKAISHI, F.M., DE ASSIS, H.C., JAKOBI, S.C., EIRAS-STOFELLA, D.R., ST-JEAN, S.D., COURTENAY, S.C., LIMA, E.F., WAGENER, A.L., SCOFIELD, A.L. and RIBEIRO, C.A., 2004. Morphological and neurotoxicological findings in tropical freshwater fish (Astyanax sp.) after waterborne and acute exposure to water soluble fraction (WSF) of crude oil. Archives of Environmental Contamination and Toxicology, vol. 46, no. 2, pp. 244-253. http://dx.doi.org/10.1007/s00244-003-2260-1. PMid:15106677.

ALBERS, P.H., 2003. Petroleum and individual polycyclic aromatic hydrocarbons. In: D.J. HOFFMAN, B.A. RATTNER, G.A. BURTON
JUNIOR and J. CAIMS JUNIOR, eds. Handbook of ecotoxicology. 2nd ed. Boca Raton: Ed. Lewis Publishers, pp. 341-371.

AL-OTAIBI, A.M., AL-BALAWI, H.F.A., AHMAD, Z. and SULIMAN, E.M., 2019. Toxicity bioassay and sublethal effects of diazinon on blood profile and histology of liver, gills and kidney of catfish, Clarias gariepinus. Brazilian Journal of Biology $=$ Revista Brasileira de Biologia, vol. 79, no. 2, pp. 326-336. http://dx.doi. org/10.1590/1519-6984.185408. PMid:30427380.

ANDERSON, J.W., NEFF, J.M., COX, B.A., TATEM, H.E. and HIGHTOWER, G.M., 1974. Characteristics of dispersions and water-soluble extracts of crude and refined oils and their toxicity to estuarine crustaceans and fish. Marine Biology, vol. 27, no. 1, pp. 75-88. http://dx.doi.org/10.1007/BF00394763.

BARBOZA, C.A.M., DOMENICO, M.D., MATTOS, G. and DEFEO, O., 2019. An oil spill is threatening Brazilian Sandy beaches [online] [viewed 19 December 2019]. E-letter Science. Available from: https:// science.sciencemag.org/content/366/6466/672/tab-e-letters

BARRON, M.G., CARLS, M.G., HEINTZ, R. and RICE, S.D., 2004. Evaluation of fish early life-stage toxicity models of chronic embryonic exposures to complex polycyclic aromatic hydrocarbon mixtures. Toxicological Sciences, vol. 78, no. 1, pp. 60-67. http://dx.doi.org/10.1093/toxsci/kfh051. PMid:14691206.

BERNET, D., SCHMIDT, H., MEIER, W., BURKHARDT-HOLM, P. and WAHLI, T., 1999. Histopathology in fish: proposal for a protocol to assess aquatic pollution. Journal of Fish Diseases, vol. 22, no. 1, pp. 25-34. http://dx.doi.org/10.1046/j.1365-2761.1999.00134.x.

BUE, B.G., SHARR, S. and SEEB, J.E., 1998. Evidence of damage to pink salmon populations inhabiting Prince William Sound, Alaska, two generations after the Exxon Valdez oil spill. Transactions of the American Fisheries Society, vol. 127, no. 1, pp. 35-43. http://dx.doi.org/10.1577/1548-8659(1998)127<0035:EODT PS>2.0.CO;2. 
CAMARGO, M.M.P. and MARTINEZ, C.B.R., 2007. Histopathology of gills, kidney and liver of a Neotropical fish caged in an urban stream. Neotropical Ichthyology, vol. 5, no. 3, pp. 327-336. http:// dx.doi.org/10.1590/S1679-62252007000300013.

ÇAVAŞ, T. and ERGENE-GÖZÜKARA, S., 2005. Micronucleus test in fish cells: a bioassay for in situ monitoring of genotoxic pollution in the marine environment. Environmental and Molecular Mutagenesis, vol. 46, no. 1, pp. 64-70. http://dx.doi. org/10.1002/em.20130. PMid:15880416.

CESTARI, M.M., LEMOS, P.M.M., RIBEIRO, C.A.O., COSTA, J.R., PELLETIER, E., FERRARO, M.V.M., MANTOVANI, M.S. and FENOCCHIO, A.S., 2004. Genetic damage induced by trophic doses of lead in the neotropical fish Hoplias malabaricus (Characiformes, Erythrinidae) as revealed by the comet assay and chromosomal aberrations. Genetics and Molecular Biology, vol. 27, no. 2, pp. 270-274. http://dx.doi.org/10.1590/S141547572004000200023.

COLLIER, T.K., KRONE, C.A., KRAHN, M.G., STAIN, J.E., CHAN, S.L. and VARANASI, U., 1996. Petroleum exposure and associated biochemical effects in subtidal fish after the Exxon Valdez oil spill. American Fishery Society Symposium, vol. 18, pp. 671-683.

COSTA, P.M., 2018. The handbook of histological practices in aquatic environments: guide to histology for environmental toxicology. Cambridge: Academic Press.

COUOH-PUGA, E.D., VIDAL-MARTÍNEZ, V.M., CEJA-MORENO, V., ÁRCEGA-CABRERA, F., PUCH-HAU, C., RODRÍGUEZ-GONZÁLEZ, A., MAY-TEC, A.L. and AGUIRRE-MACEDO, M.L., 2021. Histological effects of light crude oil on Sciaenops ocellatus under experimental conditions. Bulletin of Environmental Contamination and Toxicology. http://dx.doi.org/10.1007/ s00128-021-03172-0. PMid:33743021.

DALING, P.S., BRANDVIK, P.J., MACKAY, D. and JOHANSEN, O., 1990. Characterization of crude oils for environmental purposes. Oil and Chemical Pollution, vol. 7, no. 3, pp. 199-224. http://dx.doi. org/10.1016/S0269-8579(05)80027-9.

FERRARO, M.V.M., FENOCCHIO, A.S., MANTOVANI, M.S., RIBEIRO, C.O. and CESTARI, M.M., 2004. Mutagenic effects of tributyltin and inorganic lead ( $\mathrm{Pb}$ II) on the fish $\mathrm{H}$. malabaricus as evaluated using the comet assay and the piscine micronucleus and chromosome aberration tests. Genetics and Molecular Biology, vol. 27, no. 1, pp. 103-107. http://dx.doi.org/10.1590/S141547572004000100017

FRANTZEN, M., FALK-PETERSEN, I.B., NAHRGANG, J., SMITH, T.J., OLSEN, G.H., HANGSTAD, T.A. and CAMUS, L., 2012. Toxicity of crude oil and pyrene to the embryos of beach spawning capelin (Mallotus villosus). Aquatic Toxicology (Amsterdam, Netherlands), vol. 108, pp. 42-52. http://dx.doi.org/10.1016/j. aquatox.2011.09.022. PMid:22037118.

GERNHÖFER, M., PAWERT, M., SCHRAMM, M., MÜLLER, E. and TRIEBSKORN, R., 2001. Ultrastructural biomarkers as tools to characterize the health status of fish in contamined streams. Journal of Aquatic Ecosystem Stress and Recovery, vol. 8, no. 3-4, pp. 241-260. http://dx.doi.org/10.1023/A:1012958804442.

GOMES, L.C., CHIPPARI-GOMES, A.R., MIRANDA, T.O., PEREIRA, T.M., MERÇON, J., DAVEL, V.C., BARBOSA, B.V., PEREIRA, A.C.H., FROSSARD, A. and RAMOS, J.P.L., 2019. Genotoxicity effects on Geophagus brasiliensis fish exposed to Doce River water after the environmental disaster in the city of Mariana, MG, Brazil. Brazilian Journal of Biology = Revista Brasileira de Biologia, vol. 79 , no. 4, pp. 659-664. http://dx.doi.org/10.1590/1519-6984.188086. PMid:30462813.

HAMOUTEN, D., PAYNE, J.F., RAHIMTULA, A. and LEE, K., 2002. Use of the Comet assay to assess DNA damage in hemocytes and digestive gland cells of mussels and clams exposed to water contaminated with petroleum hydrocarbons. Marine Environmental Research, vol. 54, no. 3-5, pp. 471-474. http:// dx.doi.org/10.1016/S0141-1136(02)00162-9. PMid:12408603.

HEINTZ, R.A., RICE, S.D., WERTHEIMER, A.C., BRADSHAW, R.F., THROWER, F.P., JOYCE, J.E. and SHORT, J.W., 2000. Delayed effects on growth and marine survival of pink salmon Oncorhynchus gorbuscha after exposure to crude oil during embryonic development. Marine Ecology Progress Series, vol. 208, pp. 205-216. http://dx.doi.org/10.3354/meps208205.

JHA, A.N., 2004. Genotoxicological studies in aquatic organisms: an overview. Mutation Research, vol.552, no. 1-2, pp. 1-17. http:// dx.doi.org/10.1016/j.mrfmmm.2004.06.034. PMid:15352315.

KHAN, M.A.Q., AL-GHAIS, S.M. and AL-MARRI, S., 1995. Petroleum hydrocarbons in fish from the Arabian Gulf. Archives of Environmental Contamination and Toxicology, vol. 29, no. 4, pp. 517-522. http://dx.doi.org/10.1007/BF00208382.

LAWS, E.A., 1993. Aquatic pollution: an introductory text. New York: John Wiley.

LEE, R.F. and STEINERT, S., 2003. Use of the single cell gel electrophoresis/comet assay for detecting DNA damage in aquatic (marine and reshwater) animals. Mutation Research, vol. 544, no. 1, pp. 43-64. http://dx.doi.org/10.1016/S13835742(03)00017-6. PMid:12888107.

LEMOS, C.T., RÖDEL, P.M., TERRA, N.R., OLIVEIRA, N.C.D. and ERDTMANN, B., 2007. River water genotoxicity evaluation using micronucleus assay in fish erythrocytes. Ecotoxicology and Environmental Safety, vol. 66, no. 3, pp. 391-401. http:// dx.doi.org/10.1016/j.ecoenv.2006.01.004. PMid:16499968.

MACKAY, D. and MCAULIFFE, C.D., 1988. Fate of hydrocarbons discharged at sea. Oil and Chemical Pollution, vol. 5, no. 1, pp. 1-20. http://dx.doi.org/10.1016/S0269-8579(89)80002-4.

MASON, C.F., 1945. Biology of freshwater pollution. 3rd ed. Edinburg: Harlow.

MEDEIROS, L.C.C., DELUNARDO, F.A.C., SIMÕES, L.N., PAULINO, L.G., VARGAS, T.S., FERNANDES, M.N., SCHERER, R. and CHIPPARIGOMES, A.R., 2017. Water-soluble fraction of petroleum induces genotoxicity and morphological effects in fat snook (Centropomus parallelus). Ecotoxicology and Environmental Safety, vol. 144, pp. 275-282. http://dx.doi.org/10.1016/j.ecoenv.2017.06.031. PMid:28641238.

MIRANDA, A.L., ROCHE, H., RANDI, M.A.F., MENEZES, M.L. and RIBEIRO, C.A.O., 2008. Bioaccumulation of chlorinated pesticides and PCBs in the tropical freshwater fish Hoplias malabaricus: Histopathological, physiological, and immunological findings. Environment International, vol. 34, no. 7, pp. 939-949. http:// dx.doi.org/10.1016/j.envint.2008.02.004. PMid:18400298.

MOORE, J.W. and RAMAMOORTHY, S., 1947. Organic chemicals in natural waters: applied monitoring and impact assessment. New York: Springer-Verlag.

MOREIRA, C.B., RODRIGUES, R.V., ROMANO, L.A., GUSMÃO, E.P., SEYFFERT, B.H., SAMPAIO, L.A. and MIRANDA-FILHO, K.C., 2014. Genotoxicity and histological alterations in grey mullet Mugil liza exposed to petroleum water-soluble fraction (PWSF). Environmental Science and Pollution Research International, vol. 21, no. 8, pp. 5565-5574. http://dx.doi.org/10.1007/s11356-0132440-0. PMid:24414146.

NICODEM, D., GUEDES, C.L.B., CORREA, R.J. and FERNANDES, M.C.Z., 1997. Photochemical processes and the environmental impact of petroleum spills. Biogeochemistry, vol. 39, no. 2, pp. 121-138. http://dx.doi.org/10.1023/A:1005802027380.

OYAKAWA, O.T., 2003. Family Erythrinidae. In: R.E. REIS, S.O. KULLANDER and C.J. FERRARIS JUNIOR, eds. Check List of the 
Freshwater Fishes of South and Central America. Porto Alegre: EDIPUCRS, pp. 238-240.

PAULO, D.V., FONTES, F.M. and FLORES-LOPES, F., 2012. Histopathological alterations observed in the liver of Poecilia vivipara (Cyprinodontiformes: Poeciliidae) as a tool for the environmental quality assessment of the cachoeira River, BA. Brazilian Journal of Biology = Revista Brasileira de Biologia, vol. 72, no. 1, pp. 131-140. http://dx.doi.org/10.1590/S151969842012000100015. PMid:22437393.

PEDROZO, M.F.M., BARBOSA, E.M., CORSEUIL, H.X., SCHNEIDER, M.R. and LINHARES, M.M., 2002. Ecotoxicologia e avaliação de risco do petróleo. Salvador: Centro de Recursos Ambientais, 230 p. Série Cadernos de Referência Ambiental, vol. 12.

PÉREZ-CADAHÍA, B., LAFFON, B., PÁSARO, E. and MÉNDEZ, J., 2004. Evaluation of PAH bioaccumulation and DNA damage in mussels (Mytilus galloprovincialis) exposed to spilled Prestige crude oil. Comparative Biochemistry and Physiology. Toxicology E'Pharmacology: CBP, vol. 138, no. 4, pp. 453-460. http://dx.doi. org/10.1016/j.cca.2004.08.001. PMid:15536053.

PETERSON, C.H., RICE, S.D., SHORT, J.W., ESLER, D., BODKIN, J.L., BALLACHEY, B.E. and IRONS, D.B., 2003. Long-term ecosystem response to the Exxon Valdez oil spill. Science, vol. 302, no. 5653 , pp. 2082-2086. http://dx.doi.org/10.1126/science.1084282. PMid:14684812.

PETRY, A.C., AGOSTINHO, A.A., PIANA, P.A. and GOMES, L.C., 2007. Effects of temperature on prey consumption and growth in mass of juvenile trahira Hoplias aff. malabaricus (Bloch, 1794). Journal of Fish Biology, vol. 70, no. 6, pp. 1855-1864. http:// dx.doi.org/10.1111/j.1095-8649.2007.01461.x.

PETRY, A.C., GOMES, L.C., PIANA, P.A. and AGOSTINHO, A.A., 2010. The role of the predatory trahira (Pisces: Erythrinidae) in structuring fish assemblages in lakes of a Neotropical floodplain. Hydrobiologia, vol. 651, no. 1, pp. 115-126. http:// dx.doi.org/10.1007/s10750-010-0281-0.

PETRY, A.C., GUIMARÃES, T.F.R., VASCONCELLOS, F.M., HARTZ, S.M., BECKER, F.G., ROSA, R.S., GOYENOLA, G., CARAMASCHI, E.P., DÍAZ DE ASTARLOA, J.M., SARMENTO-SOARES, L.M., VIEIRA, J.P., GARCIA, A.M., TEIXEIRA DE MELLO, F., DE MELO, F.A., MEERHOFF, M., ATTAYDE, J.L., MENEZES, R.F., MAZZEO, N. and DI DARIO, F., 2016. Fish composition and species richness in eastern South American coastal lagoons: additional support for the freshwater ecoregions of the world. Journal of Fish Biology, vol. 89, no. 1, pp. 280-314. http://dx.doi.org/10.1111/ jfb.13011. PMid:27401481.

RAMSDORF, W.A., FERRARO, M.V.M., OLIVEIRA-RIBEIRO, C.A., COSTA, J.R.M. and CESTARI, M.M., 2009. Genotoxic evaluation of different doses of inorganic lead (PbII) in Hoplias malabaricus. Environmental Monitoring and Assessment, vol. 158, no. 1-4, pp. 77-85. http://dx.doi.org/10.1007/s10661-008-0566-1. PMid: 18843540.

RANTIN, F.T., KALININ, A.L., GLASS, M.L. and FERNANDES, M.N., 1992. Respiratory responses to hypoxia in relation to mode of life of two erythrinid species (Hoplias malabaricus and Hoplias lacerdae). Journal of Fish Biology, vol. 41, no. 5, pp. 805-812. http://dx.doi.org/10.1111/j.1095-8649.1992.tb02708.x.

RIOS, F.S., KALININ, A.L. and RANTIN, F.T., 2002. The effects of longterm food deprivation on respiration and haematology of the neotropical fish Hoplias malabaricus. Journal of Fish Biology, vol. 61, no. 1, pp. 85-95. http://dx.doi.org/10.1111/j.1095-8649.2002. tb01738.x.

SAEED, T. and AL-MUTAIRI, M., 1999. Chemical composition of the water soluble fraction of the leaded gasolines in seawater. Environment International, vol. 25, no. 1, pp. 117-129. http:// dx.doi.org/10.1016/S0160-4120(98)00093-2.

SANTOS, R.M., WEBER, L., SOUZA, V.L., SOARES, A.R. and PETRY, A.C., 2016. Effects of water-soluble fraction of petroleum on growth and prey consumption of juvenile Hoplias aff. malabaricus (Osteichthyes: erythrinidae). Brazilian Journal of Biology = Revista Brasileira de Biologia, vol. 76, no. 1, pp. 10-17. http://dx.doi.org/10.1590/1519-6984.06714. PMid:26871747.

SEDEÑO-DÍAZ, J.E. and LÓPEZ-LÓPEZ, E., 2012. Freshwater fish as sentinel organisms: from the molecular to the population level, a review. In: H. TURKER, ed. New advances and contributions to fish biology. London: IntechOpen Limited, pp. 151-173.

SILVA, C.A., OBA, E.T., RAMSDORF, W.A., MAGALHÃES, V.F., CESTARI, M.M., RIBEIRO, C.A.O. and ASSIS, H.C.S., 2011. First report about saxitoxins in freshwater fish Hoplias malabaricus through trophic exposure. Toxicon, vol. 57, no. 1, pp. 141-147. http://dx.doi. org/10.1016/j.toxicon.2010.10.015. PMid:21073887.

ŠRUT, M., TRAVEN, L., ŠTAMBUK, A., KRALJ, S., ŽAJA, R., MIĆOVIĆ, V. and KLOBUČAR, G., 2011. Genotoxicity of marine sediments in the fish hepatoma cell line PLHC-1 as assessed by the Comet assay. Toxicology In Vitro, vol. 25, no. 1, pp. 308-314. http:// dx.doi.org/10.1016/j.tiv.2010.09.015. PMid:20932891.

TRADING ECONOMICS, 2019 [viewed 19 December 2019]. Brazil crude oil production [online]. Available from: https://tradingeconomics. com/brazil/crude-oil-production

TREVISAN, O.V., FRANÇA, F.A., OKABE, C.A. and LISBOA, A.C., 2009. Elements of a heavy oil technology development program. Terrae, vol. 6, no. 1, pp. 21-29.

VANZELLA, T.P., MARTINEZ, C.B. and CÓLUS, I.M., 2007. Genotoxic and mutagenic effects of diesel oil water soluble fraction on a neotropical fish species. Mutation Research, vol. 631, no. 1, pp. 36-43. http://dx.doi.org/10.1016/j.mrgentox.2007.04.004. PMid:17509929.

WEBER, L.I., CARVALHO, L., SÁ, N., SILVA, V., BERALDINI, N., SOUZA, V. and CONCEIÇÃO, M., 2013. Genotoxic effects of the water-soluble fraction of heavy oil in the brackish/freshwater amphipod Quadrivisio aff. lutzi (Gammaridea) as assessed using the comet assay. Ecotoxicology (London, England), vol. 22, no. 4, pp. 642-655. http://dx.doi.org/10.1007/s10646-013-1055-z. PMid:23479060.

WOO, S., KIM, S., YUM, S., YIM, U.H. and LEE, T.K., 2006. Comet assay for the detection of genotoxicity in blood cells of flounder (Paralichthys olivaceus) exposed to sediments and polycyclic aromatic hydrocarbons. Marine Pollution Bulletin, vol. 52, no. 12, pp. 1768-1775. http://dx.doi.org/10.1016/j. marpolbul.2006.08.027. PMid:17010996.

ZHOU, S., HERAS, H. and ACKMAN, R.G., 1994. Preparation and characterization of a water-soluble fraction of crude oil by a Karr reciprocating-plate countercurrent extraction column. Archives of Environmental Contamination and Toxicology, vol. 26, no. 4, pp. 527-533. http://dx.doi.org/10.1007/BF00214157. 